\title{
Fibre type and concentration in the lungs of workers in an asbestos cement factory
}

\author{
B GYLSETH, ${ }^{1}$ G MOWÉ, ${ }^{1}$ AND A WANNAG ${ }^{2}$ \\ From the Institute of Occupational Health, ${ }^{1}$ Oslo, and Norcem $A / S,{ }^{2}$ Slemmestad, Norway
}

ABSTRACT The predominant asbestos fibre type used in the production of asbestos cement is chrysotile. The use of asbestos in relation to fibre type in a Norwegian asbestos cement plant during $1942-80$ was $91.7 \%$ chrysotile, $3 \cdot 1 \%$ amosite, $4 \cdot 1 \%$ crocidolite, and $1 \cdot 1 \%$ anthophyllite respectively. Electron microscopy and $x$ ray microanalysis of lung tissue samples of asbestos cement workers who had died of malignant pleural mesothelioma or bronchogenic carcinoma showed a completely inverse ratio with regard to fibre type. The percentage of chrysotile asbestos in lung tissue varied between $0 \%$ and $9 \%$ whereas the corresponding numbers for the amphiboles were $76 \%$ and $99 \%$. These differences are discussed with respect to the behaviour of different fibre types in the human body and to the occurrence of malignant mesothelioma in this asbestos cement factory.

Analysis of fibres in human lung tissue may be used for the verification of previous exposure to asbestos. The amount of fibres deposited in the lungs may also reflect the total dose (concentration $x$ years of exposure) to which an individual has been exposed. Nevertheless, variations in deposition, clearance rate, and durability of different types of fibres should be borne in mind when such data are compared. The fact that chrysotile is cleared more efficiently or even dissolved in lung tissue often results in a relatively larger percentage of amphibole fibres in the lung provided that a mixed type asbestos exposure has occurred. This difference is especially important in cases of mesothelioma as it has been argued that crocidolite has the highest mesothelioma producing potential followed by amosite and chrysotile, ${ }^{1}$ an assumption supported by the studies of Dement $e$ t al and Weiss who reported no mesotheliomas in two plants where only chrysotile had been used. ${ }^{23}$ Contrary to these reports, Newhouse et al found 10 mesotheliomas in a cohort apparently exposed only to chrysotile. ${ }^{4}$ The association between fibre type and disease has been further clarified by McDonald $e t$ al who showed that cases of mesothelioma and referents were similar with respect to chrysotile content in the lungs, whereas there was a substantial excess of amosite and crocidolite in the cases compared with the referents. $^{5}$

Received 29 September 1982 Accepted 22 November 1982
Chrysotile is the predominant asbestos fibre type used in the production of asbestos cement. Crocidolite, amosite, and anthophyllite have to a far lesser extent been used, generally for special purposes.

In order to study the relation between the use of asbestos and fibre deposition we have performed an investigation in a Norwegian asbestos cement factory that started production in 1942 and closed down in 1980. The annual number of employees in the factory before 1960 was about 200 . The use of asbestos from various sources with relation to fibre type was: $91.7 \%$ chrysotile, $3.1 \%$ amosite, $4.1 \%$ crocidolite, and $1.1 \%$ anthophyllite. According to factory records anthophyllite asbestos was used only from 1942 to 1945 .

The object of this study was to compare the use of asbestos and exposure to asbestos in the factory with the number and type of fibres found in samples of lung tissue from four cases of malignant pleural mesothelioma and four cases of bronchogenic carcinoma.

\section{Materials and methods}

Samples of lung tissue were obtained from necropsy or lobectomy as formaline preserved tissue pieces, or as tissue embedded in paraffin blocks. In the first case the wet tissue was cut into small pieces and dried to constant weight at $60-70^{\circ} \mathrm{C}$. In the latter case the paraffin was removed by xylene and the tissue was cut and dried. Twenty to 50 milligrams of 
dried tissue were weighed and ashed in a Tracerlab 505 low temperature plasma asher (LTA) at $60 \mathrm{~W}$ forward power and at an oxygen flow of $225 \mathrm{ml} / \mathrm{min}$. The ash was suspended in a $\mathbf{0 . 5} \mathrm{N}$ hydrochloric acid solution containing $10 \%$ ethanol for five minutes' treatment in an ultrasonic bath. The chemical solutions used were all filtered twice before use.

Only acid/detergent washed glass equipment was used. The ash suspensions were filtered on Nuclepore polycarbonate membranes with $47 \mathrm{~mm}$ diameter and $0.2 \mu \mathrm{m}$ pore size. To avoid contamination, the membranes were kept in closed petri dishes. Pieces of the Nuclepore membranes were either coated by gold or carbon. The gold coated specimens were investigated in a Jeol JMS-35 scanning electron microscope (SEM). The number of fibres was recorded directly from the screen at $4500 \times$ magnification in the slow scanning mode. At least 200 fields or 100 fibres, whichever was completed first, were counted. The carbon coated samples were prepared for transmission electron microscopy (TEM) by dissolving the polycarbonate membrane from the carbon film with chloroform. The carbon film, with the fibres embedded, was transferred to a 150 mesh Ni-grid. These specimens were investigated in a Jeol 100 C TEM fitted with a 148 $\mathrm{eV}$ resolution and $30 \mathrm{~mm}^{2}$ area $\mathrm{Si}(\mathrm{Li})$ detector. Using this system we could identify single chrysotile fibrils by morphology and chemistry as well as separating between very thin crocidolite and amosite fibres.

\section{Results}

\section{USE OF ASBESTOS}

Figure 1 shows the annual use of asbestos from 1942 to 1980 , based on data obtained from factory records. Finnish asbestos (anthophyllite) was used

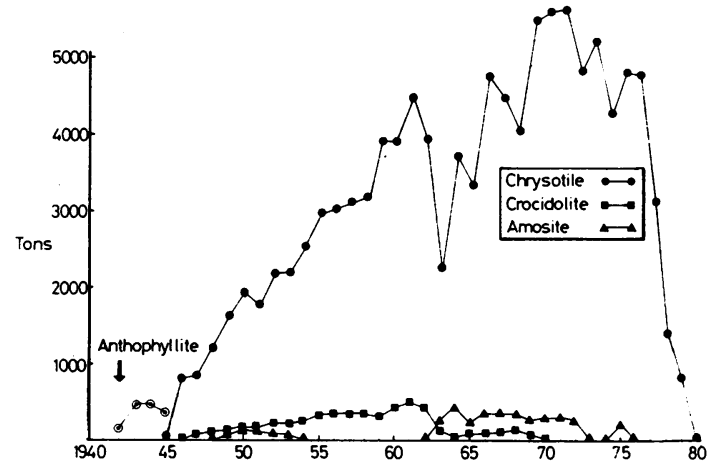

Fig 1 Annual use in tons of different types of asbestos in a Norwegian asbestos cement factory during 1942-80.

only from 1942 to 1945 . We identified the highest concentration of anthophyllite fibres in the lungs of three workers employed from the beginning of production. As shown, chrysotile has, however, been the major raw material during all the years of production.

\section{EXPOSURE DATA}

In a report from the factory inspectorate in 1950 fibre concentrations varying from $3.6-70 \mathrm{mppcf}$ were recorded. In another report in 1954 the concentrations were 3.4-15.4 mppcf. In 1964 the Institute of Occupational Health in Oslo made a survey based on gravimetric measurements and midgetimpingers. The gravimetric data showed concentrations from $0 \cdot 2-22 \cdot 8 \mathrm{mg} / \mathrm{m}^{3}$ whereas the corresponding midget-impinger results were 5:2-113 mppcf. The asbestos content of the dust was 40$60 \%$. From 1972 to 1980 fibre concentrations were regularly recorded by the company using the membrane technique. During sacking operations, fibre

Table 1 Case information

\begin{tabular}{|c|c|c|c|c|c|c|c|}
\hline $\begin{array}{l}\text { Case } \\
\text { No }\end{array}$ & $\begin{array}{l}\text { Year at } \\
\text { first } \\
\text { exposure }\end{array}$ & $\begin{array}{l}\text { Age at } \\
\text { first } \\
\text { exposure } \\
\text { (years) }\end{array}$ & $\begin{array}{l}\text { Duration } \\
\text { of } \\
\text { exposure } \\
\text { (years) }\end{array}$ & $\begin{array}{l}\text { Latency from } \\
\text { furst exposure } \\
\text { until death } \\
\text { (years) }\end{array}$ & $\begin{array}{l}\text { Age at } \\
\text { diagnosis } \\
\text { (years) }\end{array}$ & $\begin{array}{l}\text { Source of } \\
\text { tissue }\end{array}$ & Diagnosis \\
\hline 1 & 1942 & 39 & 29 & 33 & 72 & Necropsy & \multirow{8}{*}{$\begin{array}{l}\text { Pleural mesothelioma. } \\
\text { Mixed type. Asbestosis } \\
\text { Pleural mesothelioma. } \\
\text { Mixed type } \\
\text { Pleural mesothelioma. } \\
\text { Sarcomatous } \\
\text { Pleural mesothelioma. } \\
\text { Mixed type } \\
\text { Bronchial cancer. } \\
\text { Oat cell carcinoma } \\
\text { Bronchial cancer. } \\
\text { Squamous cell carcinoma } \\
\text { Bronchial cancer. } \\
\text { Squamous cell carcinoma } \\
\text { Not classified }\end{array}$} \\
\hline 2 & 1945 & 21 & 33 & 33 & 54 & Necropsy & \\
\hline 3 & 1951 & 42 & 22 & 21 & 63 & Necropsy & \\
\hline 4 & 1942 & 27 & 20 & 38 & 62 & Necropsy & \\
\hline 5 & 1949 & 31 & 4 & 30 & 61 & Necropsy & \\
\hline 6 & 1959 & 51 & 13 & 20 & 71 & Necropsy & \\
\hline 7 & 1949 & 33 & 30 & 31 & 64 & Lobectomy & \\
\hline 8 & 1942 & 16 & 4 & 34 & 50 & Lobectomy & \\
\hline
\end{tabular}


Table 2 Concentration and type of fibres in lung tissue samples

\begin{tabular}{|c|c|c|c|c|c|c|c|}
\hline Date & $\begin{array}{l}\text { Fibre concentration } \\
\text { determined by SEM } \\
\text { (million fibres per gram } \\
\text { dried tissue) }\end{array}$ & $\begin{array}{l}\text { No of fibres } \\
\text { analysed by EDS }\end{array}$ & $\begin{array}{l}\text { Crocido- } \\
\text { lite (\%) }\end{array}$ & $\underset{(\%)}{\text { Amosite }}$ & $\begin{array}{l}\text { Antho- } \\
\text { phyllite } \\
\text { (\%) }\end{array}$ & $\begin{array}{l}\text { Chryso- } \\
\text { tile (\%) }\end{array}$ & $\begin{array}{l}\text { Others* } \\
\text { (\%) }\end{array}$ \\
\hline $\begin{array}{l}1 \\
2 \\
3 \\
4 \\
5 \\
6 \\
7 \\
8\end{array}$ & $\begin{array}{c}112 \\
490 \\
83 \\
206 \\
6 \cdot 1 \\
49 \\
34 \\
7.5\end{array}$ & $\begin{array}{r}107 \\
72 \\
102 \\
53 \\
28 \\
22 \\
61 \\
33\end{array}$ & $\begin{array}{r}56 \\
68 \\
74 \\
60 \\
36 \\
55 \\
85 \\
6\end{array}$ & $\begin{array}{r}6 \\
17 \\
11 \\
2 \\
14 \\
32 \\
11 \\
-\end{array}$ & $\begin{array}{r}28 \\
3 \\
8 \\
34 \\
14 \\
5 \\
2 \\
70\end{array}$ & $\begin{array}{l}7 \\
8 \\
2 \\
- \\
9 \\
-\end{array}$ & $\begin{array}{c}4 \\
4 \\
6 \\
4 \\
36 \\
1 \\
24 \dagger\end{array}$ \\
\hline
\end{tabular}

* Others comprise tremolite, mullite, and non-identified silicate fibres.

$+10 \%$ Mullite.

SEM = Scanning electron microscopy.

$\mathrm{EDS}=$ Energy dispersive $\boldsymbol{x}$ ray microanalysis.

concentrations up to $13 \mathrm{fibres} / \mathrm{cm}^{3}$ were detected, but after 1973 the exposures were generally lower than $5 \mathrm{fibres} / \mathrm{cm}^{3}$.

\section{LUNG TISSUE ANALYSES}

Table 1 shows the data for eight cases while table 2 gives the fibre concentrations and types of asbestos found in lung tissue. Although more than $90 \%$ of all asbestos used in the factory was chrysotile, the result for the lung tissue analyses is completely reversed. The percentage of chrysotile compared with the total number of fibres varied from $0 \%$ to $9 \%$ whereas the corresponding number for the amphiboles (excluding case 5) varied between $76 \%$ and $99 \%$. Case No 5 was not directly employed by the asbestos cement company but worked for a construction company inside the factory area. Cases 1 , 4 , and 8 had been employed since 1942 by the asbestos company. This is reflected in a significant number of anthophyllite fibres in their lungs, especially for case No 8 where anthophyllite constituted $70 \%$ of the fibres. Figure 2 shows a characteristic TEM-micrograph of fibres in an ashed lung sample from case No 2. Figure 3(a) and (b) shows the characteristic spectra of very thin chrysotile and crocidolite fibres. Other fibres such as tremolite (fig 3c) and mullite were found, but those were classified as "others" along with unidentified silicate fibres. In case $5,36 \%$ of the fibres were classified as "others" due to the large amounts of other particles interfering during $x$ ray microanalysis.

\section{Discussion}

Although more than $90 \%$ of the fibres used in the production of asbestos cement was chrysotile,

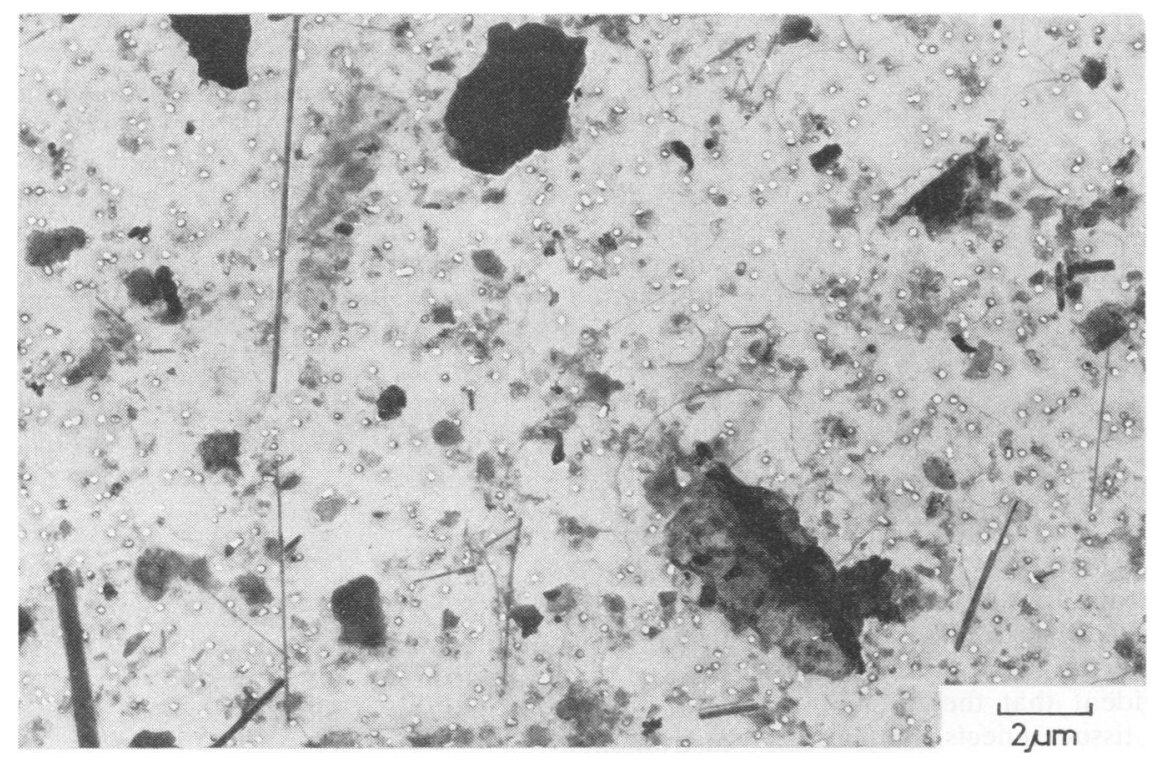

Fig 2 Characteristic fibres found in lung tissue of case No 2 photographed in transmission electron microscope at $6250 \times$ magnification. 

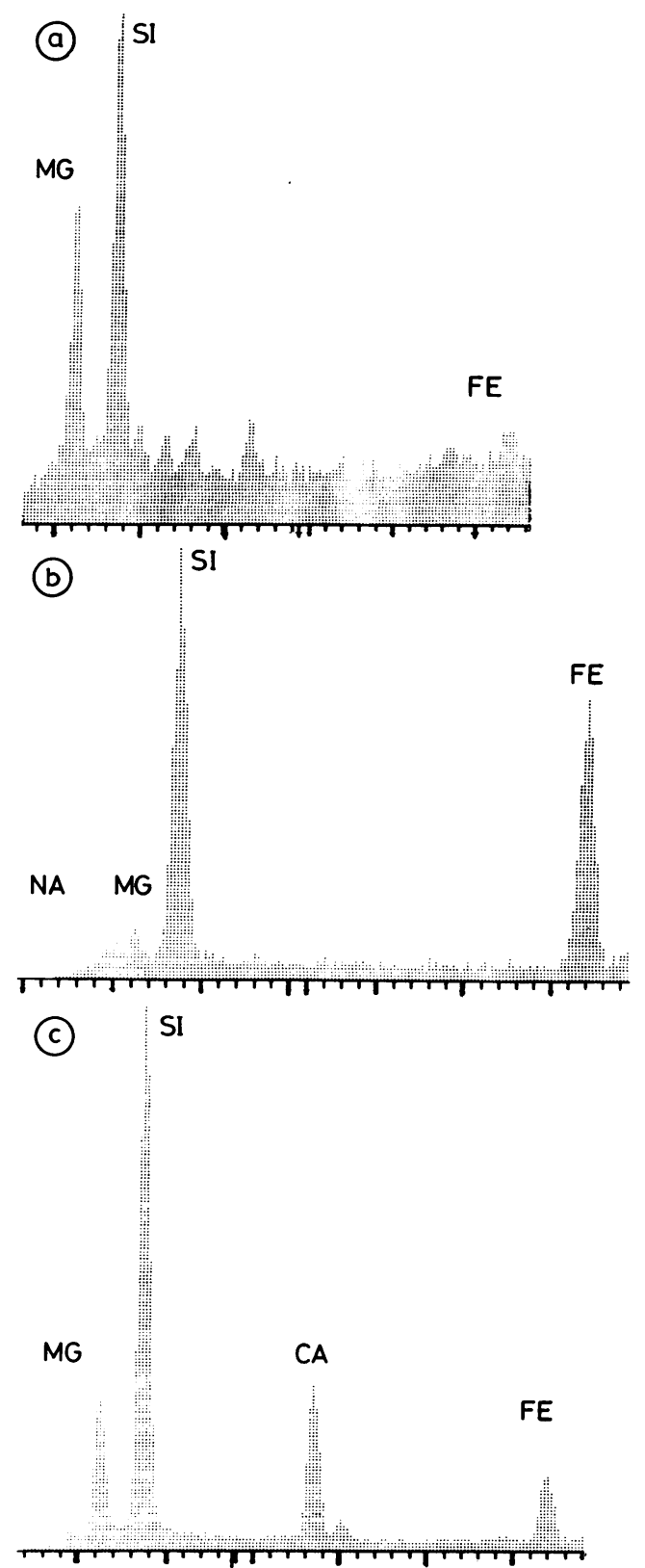

Fig 3 Energy dispersive $x$ ray spectra: (a) chrysotile asbestos, (b) crocidolite asbestos, (c) tremolite asbestos.

amphibole fibres were mainly found in the samples of lung tissue. This might be due to factors such as differential clearance, penetration, and durability of the fibre types. It is evident that the number of chrysotile fibres in lung tissue reflects neither the total asbestos dose inhaled nor the exposure level to which these workers had been exposed. Walton states that crocidolite is reputedly a more dusty material than chrysotile, ${ }^{6}$ but this alone cannot explain the large differences in the amount of fibres deposited. It is unlikely that the differences found in this study are due to the higher "dustiness" of the amphiboles.

The study further indicates that exposure to asbestos, expressed as high amounts of amphibole fibres deposited in the lungs of the workers, has been considerable for many years, especially in the cases of mesothelioma. This difference in fibre concentration between those with mesothelioma and those with bronchogenic carcinoma may be due to different exposure times or intensity of exposure; or it may be that some people deposit a higher proportion of fibres in the lung and are thus more prone to disease than others.

The anthophyllite fibres found in the lungs of the workers employed after the period when anthophyllite was used may originate from the contamination of the other asbestos types or from unknown exposure.

Recent reports from the asbestos cement industry $^{7-12}$ have indicated low frequencies of malignant mesothelioma. This may be due to the underdiagnosis of this tumour, as suggested by Weill, ${ }^{7}$ or to the use of chrysotile as the predominant type of asbestos. A recent study by Thomas et al gives further evidence to the view that chrysotile is a less potent cause of mesothelioma than amphiboles. ${ }^{12}$ In this study two cases of mesothelioma were found in a group exposed to crocidolite and chrysotile before 1936 , but after 1936, when chrysotile only was used, no further mesotheliomas were detected.

In a study on the incidence of malignant mesothelioma in Norway from 1970 to 1979 six cases were recorded among asbestos cement workers. ${ }^{13}$ Since then, three additional cases have been registered from the same plant. The previous consumption of crocidolite and amosite has probably contributed to the high number of malignant mesothelioma in this plant.

Reprint requests to: Dr B Gylseth, Institute of Occupational Health, PO Box 8149, Dep, Oslo 1, Norway.

We thank the Royal Norwegian Council for Scientific and Industrial Research for financial support and Electron microscopy laboratory for Bioscience, University of Oslo, for loaning us the instruments. 


\section{References}

' McDonald JC, McDonald AD. Epidemiology of mesothelioma from estimated incidence. Prev Med 1977;6:426-46.

${ }^{2}$ Dement JM, Harris RL, Symons MJ, Shy C. Estimates of dose-response for respiratory cancer among chrysotile asbestos textile workers. In: Walton WH, ed. Inhaled particles $V$. Oxford: Pergamon Press, 1982: 869-87.

${ }^{3}$ Weiss W. Mortality of a cohort exposed to chrysotile asbestos. JOM 1977;19:737-40.

4 Newhouse ML, Berry G, Skidmore JN. A mortality study of workers manufacturing friction materials with chrysotile asbestos. In : Walton WH, ed. Inhaled particles $V$. Oxford: Pergamon Press, 1982; 899-909.

${ }^{5}$ McDonald AD, McDonald JC, Pooley FD. Mineral fibre content of mesothelial tumours in North America. In: Walton WH, ed. Inhaled particles $V$. Oxford: Pergamon Press, 1982; 417-22.

6 Walton WH. The nature, hazard and assessment of occupational exposure to airborne asbestos dust: a review. Ann Occup Hyg 1982;25:180-1.

' Weill H, Hughes J, Waggenspack C. Influence of dose and fiber type on respiratory malignancy risk in asbestos cement manu- facturing. Am Rev Respir Dis 1979;120:345-54.

B Clemmesen J, Hjalgrim-Jensen S. Cancer incidence among 5686 asbestos-cement workers followed from 1943 through 1976. Ecotoxicol Environ Safety 1981;5:15-20.

- Lacquet LM, van der Linden L, Lepoutre J. Roentgenographic lung changes, asbestosis and mortality in a Belgian asbestoscement factory. In: Wagner JC, ed. Biological effects of mineral fibres. Lyon: International Agency for Research on Cancer, 1980; 783-93. (Scientific publication No 30.)

${ }^{10}$ Ohlson CG, Hogstedt CA. A cohort study on mortality among Swedish asbestos cement workers. Prevention of occupational cancer-international symposium, ILO. Occupational Safety and Health Series 1982;46:196-204.

"Finkelstein MM. Asbestosis in long-term employees of an Ontario asbestos-cement factory. Am Rev Respir Dis 1982;125:496-501.

12 Thomas HF, Benjamin II, Elwood PC, Sweetnam PM. Further follow-up study of workers from an asbestos cement factory. Br J Ind Med 1982;39:273-6.

${ }^{13}$ Mowe G. Time trend in the incidence of malignant mesothelioma in Norway 1970-1979. Prevention of occupational cancerinternational symposium, ILO. Occupational Safety and Health Series 1982;46:213-9. 
sion was used to distinguish men without and with material quantities of lung dust. The groups were equally represented among the men from the several sources except for the epidemiological unit's random sample which, as might be expected, consisted predominantly of categories 0 and 1 . The men who were referred from the Pneumoconiosis Medical Panel had found their way there as a result of a National Coal Board periodic $x$-ray examination; they met the same selection criteria as the other subjects. Thus while the sampling procedure was not ideal it was not obviously biased in favour of the more disabled men being those with the higher categories of pneumoconiosis. In this our sample may have been better than that cited by Cochrane and Moore; their usable data came mainly from the
Staveley survey of which one of the conclusions was that men moved to those coal mines had above average respiratory health. A more definitive population might be drawn by the NCB but meanwhile our findings appear to be not unrepresentative: we hope that they will stimulate others to carry the subject further.

\section{References}

' Higgins ITT. Tobacco smoking, respiratory symptoms, and ventilatory capacity. Studies in random samples of the population. Br Med J 1959; i:325-9.

${ }^{2}$ Higgins ITT, Cochrane AL, Gilson JC, Wood CD. Population studies of chronic respiratory disease. A comparison of miners, foundryworkers, and others in Staveley, Derbyshire. Br J Ind Med 1959;16:255-68.

\section{Notice}

\section{Royal College of Physicians of Ireland:} Faculty of Occupational Medicine

Parts I and II of the examination for the membership of the faculty will be held in May and November each year. Details may be obtained from the Examination Office, Royal College of Physicians of Ireland, 6 Kildare Street, Dublin 2.

\section{Correction}

Fibre type and concentration in the lungs of workers in an abestos cement factory (Nov 1983)

It has been brought to my attention that the interpretation which we made $(\mathrm{Br} J$ Ind Med 1983:40;375-9) of results published by Newhouse and her colleagues ${ }^{1}$ was incorrect. In our paper we stated (in the first paragraph of the paper) that these authors found ten mesotheliomas in a cohort apparently exposed only to chrysotile. In fact, eight of the ten patients with mesothelioma in that study had had a definite exposure to crocidolite during one specific job.

B Gylseth, Institute of Occupational Health, Oslo 1, Norway.

' Newhouse ML, Berry G, Skidmore JW. A mortality study of workers manufacturing friction materials with chrysotile asbestos. Ann Occup Hyg 1982:26;899-909. 